\title{
AKTIVITAS ANTIBAKTERI EKSTRAK KULIT PISANG KEPOK KUNING (Musa paradisiaca L.) TERHADAP BAKTERI Staphylococcus aureus DAN Escherichia coli SERTA PENENTUAN TOTAL FLAVONOID DAN FENOL DALAM FRAKSI AKTIF
}

\author{
N. K. D. M. S. Wahyuni*, W. S. Rita, dan I. A. R. A. Asih \\ Program Studi Kimia FMIPA Universitas Udayana, Bukit Jimbaran, Bali \\ *E-mail: kadekdyan10@yahoo.com
}

\begin{abstract}
ABSTRAK
Kulit pisang kepok kuning (Musa paradisiaca L.) belum dimanfaatkan secara optimal, sementara kulit tersebut dapat digunakan sebagai obat infeksi. Tujuan dari penelitian ini adalah untuk mengetahui aktivitas ekstrak kulit pisang kapok kuning terhadap bakteri Staphylococcus aureus dan Escherichia coli serta mengetahui kandungan total flavonoid dan fenol pad ekstrak aktif. Ekstraksi kulit pisang kepok kuning dilakukan dengan menggunakan metode maserasi dan partisi, pengujian aktivitas antibakteri dilakukan dengan metode sumur difusi, dan penentuan kandungan total flavonoid dan fenol dilakukan dengan Spektrofotometer UV-Vis. Maserasi $1 \mathrm{~kg}$ serbuk kulit pisang kepok kuning menghasilkan 80,9173 g ekstrak kental etanol. Hasil partisi $20 \mathrm{~g}$ ekstrak kental etanol menghasilkan 1,3758 g ekstrak n-heksana, 3,5818 g ekstrak etil asetat, dan 1,0762 g ekstrak n-butanol. Hasil uji antibakteri terhadap bakteri S.aureus dan E.coli menunjukkan bahwa ektrak n-butanol $10 \%$ memiliki aktivitas yang tergolong kuat dibandingkan dengan ekstrak etanol, etil asetat, dan n-heksana. Nilai Konsentrasi Hambat Minimum (KHM) dari ekstrak n-butanol sebesar $0,5 \%$ untuk bakteri S.aureus dan 0,1\% untuk bakteri E.coli. Kandungan total flavonoid dan fenol ekstrak n-butanol berturut-turut adalah $0,06 \%$ dan $0,15 \%$.
\end{abstract}

Kata kunci : kulit pisang kepok kuning, Staphylococcus aureus, Escherichia coli, antibakteri, flavonoid, fenol

\begin{abstract}
Peel of yellow kepok banana (Musa paradisiaca L) has not been used optimally, while the peel can be used as an infection medicine The aim of this study was to reveal the activity of kepok yellow banana peel extract against Staphylococcus aureus and Escherichia coli and to determine the total content of flavonoids and phenols in active extract.. Extraction peel of yellow kepok banana was done by maceration and partition method, anti bacterial activity was assayed by wells diffusion method, determination total flavonoid and phenolic contents was done by UV-Vis Spectrophotometer. Maceration of $1 \mathrm{~kg}$ peel of yellow banana produced $80.9173 \mathrm{~g}$ of crude ethanol extract. The partition of $20 \mathrm{~g}$ crude ethanol extract produced $1.3758 \mathrm{~g}$ of $\mathrm{n}$-hexane extract, $3.5818 \mathrm{~g}$ of ethyl acetate extract, and $1.0762 \mathrm{~g}$ of n-butanol extract. Anti bacterial test result showed that the $10 \% \mathrm{n}$-butanol extract was active towards S.aureus and E.coli with strong activity compared with ethanol, ethyl acetate, and n-hexane extract. MIC value was $0.5 \%$ for S.aureus and 0,2\% for E.coli bacteria. The total contents of flavonoid and phenol in n-butanol extract respectively were $0.06 \%$ and $0.15 \%$.
\end{abstract}

Keywords: peel of yellow kepok banana, Staphylococcus aureus, Escherichia coli, antibacterial, flavonoid, phenol

\section{PENDAHULUAN}

Tanaman pisang kepok kuning (Musa paradisiaca L.) merupakan salah satu tanaman yang dapat dijadikan sebagai alternatif obat secara tradisional. Sebagian besar masyarakat gemar mengkonsumsi buah pisang karena memiliki kandungan gizi yang baik untuk kesehatan, mudah diperoleh, dan rasanya yang enak. Terdapat tiga gula alami yang terkandung pada buah pisang yaitu fruktosa, sukrosa, dan glukosa dengan serat. Pisang memberikan tambahan energi yang instan, berkelanjutan, dan substansial. Penelitian telah membuktikan bahwa dengan mengkonsumsi dua pisang dapat memberikan energi yang cukup untuk latihan berat selama 90 menit (Kumar et al., 2012). Semakin meningkatnya 
konsumsi terhadap buah pisang, akan menyebabkan penumpukan limbah atau sampah kulit pisang. Pemanfaatan limbah kulit pisang sebagai olahan pangan telah banyak dilakukan, tetapi pemanfaatan kulit pisang yang berkenaan dengan komponen senyawa aktif yang terkandung didalamnya masih terbatas. Kulit buah pisang masak yang berwarna kuning mengandung banyak senyawa flavonoid dan juga fenolik (Atun et al., 2007). Analisis fitokimia terhadap kulit pisang kepok kuning (Musa paradisiaca L.) positif mengandung flavonoid, saponin, alkaloid, dan tanin yang dapat menghambat aktivitas bakteri Staphylococcus aureus dan Eschericia coli (Ningsih et al., 2013).

Escherichia coli dan Staphylococcus aureus adalah bakteri patogen yang biasanya menyerang manusia. Bakteri S.aureus dapat menyebabkan infeksi seperti bisul, jerawat, osteomielitis, meningitis, mastitis, dan pneumonia, dan hidup saprofit di dalam saluran membran tubuh manusia, kelenjar keringat, serta saluran usus. Sedangkan bakteri E.coli dapat menimbulkan penyakit infeksi saluran kemih, diare, dan infeksi luka serta terdapat di dalam usus besar manusia (Karsinah et al., 1994).

Menurut Faradhila (2015), bakteri penyebab jerawat yaitu Propionibacterium acne, Staphylococcus epidermidis, serta Staphylococcus aureus mampu dihambat aktivitas pertumbuhannya oleh ekstrak etanol limbah kulit pisang kepok kuning (Musa paradisiaca L.). Ekstrak etanol $96 \%$ tersebut memiliki sensitivitas tinggi terhadap bakteri Propionibacterium acne pada konsentrasi $25.000 \mathrm{ppm}$ dengan diameter hambat sebesar $8,4 \mathrm{~mm}$. Aktivitas penghambatan kulit pisang kemungkinan disebabkan oleh adanya senyawa flavonoid dan fenol.Fagbemi et al., 2009 melaporkan bahwa ekstrak etanol dan air dari buah pisang (Musa sapientum) menunjukkan aktivitas penghambatan yang baik terhadap bakteri Salmonella paratyphi, S.aureus, Shigella flexnerii, Klebsiella pneumoniae, E.coli, Pseudomonas aeruginosa, dan Bacillus subtilis dengan Konsentrasi Hambat Minimum (KHM) berkisar antara 2-512 $\mathrm{mg} / \mathrm{ml}$ dan 32$512 \mathrm{mg} / \mathrm{ml}$. Kemudian Subrata et al., 2011 melaporkan bahwa ekstrak etanol akar Musa paradisiaca Lam. menunjukkan aktivitas yang cukup dalam menghambat bakteri gram positiv (B.megaterium, S.aureus, B.subtilis) dan gram negatif (S.dysenteriae, E.coli, P.aeruginosa, S.typhi, S.flexneri, dan Vibrio cholerae) dengan zona hambat mulai dari $10.53 \pm 0.37$ hingga $12.42 \pm 0.85 \mathrm{~mm}$ pada konsentrasi 500 $\mu \mathrm{g} /$ disk.

Berdasarkan uraian tersebut, maka tujuan dari penelitian ini adalah untuk mengetahui aktivitas antibakteri kulit pisang kepok kuning (Musa paradisiaca L.) yang lebih spesifik terhadap bakteri Staphylococcus aureus dan Escherichia coli serta menentukan kandungan total flavonoid dan fenol dalam fraksi yang mampu menghambat pertumbuhan bakteri Staphylococcusaureus dan Escherichia coli dengan aktivitas tertinggi.

\section{MATERI DAN METODE}

\section{Bahan}

Bahan yang digunakan pada penelitian ini adalah kulit buah pisang kepok kuning (Musa paradisiaca L.) yang diperoleh di kawasan Denpasar, Bali. Bahan kimia yang digunakan adalah etanol 96\%, n-heksana (teknis), etil asetat (p.a), n-butanol (p.a), aquades, besi (III) klorida $\left(\mathrm{FeCl}_{3}\right)$, asam klorida $(\mathrm{HCl})$, serbuk $\mathrm{Mg}$, natrium hidroksida $(\mathrm{NaOH})$, media agar (Nutrient Agar), tetrasiklin, tween 80 , kuersetin, metanol, asam galat, Folin-Ciocalteau, natrium karbonat $\left(\mathrm{Na}_{2} \mathrm{CO}_{3}\right)$, dan aluminium klorida $\left(\mathrm{AlCl}_{3}\right)$.

\section{Peralatan}

Peralatan yang digunakan yaitu seperangkat alat gelas, kapas, kain kasa, aluminium foil, kertas saring, gunting, pisau, neraca elektronik, blender, penangas air, ose, autoklaf, Laminar Air Flow, inkubator, jangka sorong/mistar, bunsen, oven, pinset, vacuum rotary evaporator, dan Spektrofotometer ultraviolet-visible (UV-Vis).

\section{Cara Kerja \\ Penyiapan bahan}

Limbah kulit pisang sebanyak $10 \mathrm{~kg}$ dibersihkan dan dirajang kecil-kecil untuk memudahkan proses pengeringan. Setelah kering, kulit pisang diblender sampai menjadi serbuk.

\section{Ekstraksi kulit pisang kepok kuning (Musa paradisiaca L.)}

Sebanyak $1 \mathrm{~kg}$ serbuk kering kulit pisang kepok kuning (Musa paradisiaca L.) 
dimaserasi menggunakan etanol 96\%. Proses maserasi dilakukan 2 kali selama 5 hari dengan pergantian pelarut pada hari ke tiga tanpa terkena paparan sinar matahari. Ekstrak yang diperoleh kemudian diuapkan menggunakan rotary vacuum evaporator sampai diperoleh ekstrak kental etanol (ekstrak kasar). Selanjutnya ekstrak kasar sebanyak 80,92 gram dilarutkan dalam etanol : air (7:3) dan diuapkan kembali untuk menghilangkan etanolnya. Ekstrak air yang diperoleh dipartisi menggunakan n-heksana, etilasetat dan nbutanol. Ekstrak n-heksana, etilasetat, nbutanol, dan etanol selanjutnya dilakukan pengujian flavonoid dan fenol.

\section{Uji fitokimia senyawa flavonoid dan fenol}

Uji fitokimia flavonoid dilakukan dengan test Willstatter, Bate-Smith-Metcalfe, dan $\mathrm{NaOH} 10 \%$. Test Willstatter dilakukan dengan menambahkan asam klorida $(\mathrm{HCl})$ pekat dan serbuk Mg. Test Bate-SmithMetcalfe dilakukan dengan menambahkan HCL pekat kemudian dipanaskan. Test $\mathrm{NaOH}$ $10 \%$ dilakukan dengan menambahkan beberapa tetes $\mathrm{NaOH} 10 \%$. Uji positif flavonoid ditunjukkan dengan perubahan warna yang terjadi. Reaksi warna flavonoid disajikan pada Tabel Geissman, 1962. Sedangkan uji fitokimia fenol dilakukan dengan menambahkan pereaksi $\mathrm{FeCl}_{3} \quad 1 \%$ dengan perubahan warna menjadi hijau, biru, atau ungu.

\section{Pengujian aktivitas antibakteri}

Pengujian aktivitas antibakteri ekstrak kulit pisang kepok kuning (Musa paradisiaca L.) dilakukan dengan metode sumur difusi agar pada konsentrasi ekstrak 10\% (b/v). Sebanyak $1 \mathrm{~mL}$ suspensi bakteri ditambahkan ke dalam 20 media agar. Kemudian divorteks hingga homogen dan dipadatkan di dalam cawan petri steril, lalu sumur dengan diameter $\pm 6 \mathrm{~mm}$ dibuat dengan menggunakan preforator. Sebanyak $20 \mu \mathrm{L}$ ekstrak uji, kontrol negatif (tween 10\%), kontrol positif (tetrasiklin) dimasukkan ke dalam sumur dan inkubasi selama 24 jam dengan suhu $37^{\circ} \mathrm{C}$. Diameter hambat yang terbentuk diamati setelah periode inkubasi. Zona penghambatan senyawa antibakteri dari ekstrak kulit pisang kepok kuning diukur berdasarkan diameter $(\mathrm{mm})$ penghambatan berupa areal bening di sekeliling sumur uji.

\section{Penentuan konsentrasi hambat minimum (KHM)}

Metode yang digunakan dalam penentuan KHM yaitu sumur difusi agar. Ekstrak uji dibuat dengan berbagai konsentrasi mulai dari 0,$2 ; 0,5 ; 1,0 ; 2,0 ; 4,0 ; 6,0 ;$ dan $8,0 \%$ $(\mathrm{v} / \mathrm{v})$. Sebanyak $20 \mu \mathrm{L}$ ekstrak uji dan kontrol negatif (tween 10\%) dimasukkan ke dalam sumur. Inkubasi dilakukan selama 24 jam pada suhu $37^{\circ} \mathrm{C}$ untuk bakteri. Hasil diamati dengan melihat ada atau tidaknya aktivitas antibakteri Eschericia coli dan Staphylococcus aureus serta mengukur diameter hambatnya (Sari et al., 2014).

\section{Penentuan kandungan total flavonoid}

Metode yang digunakan dalam penetapan kadar flavonoid total adalah metode kolorimetri dengan kuersetin (QE) sebagai standar (Chang dan Wen, 2002).

Sebanyak 0,1 gram sampel (ekstrak nbutanol) ditimbang kemudian dilarutkan ke dalam labu ukur $5 \mathrm{~mL}$ menggunakan etanol $50 \%$. Filtrat yang diperolehz direaksikan dengan etanol $50 \%$ dengan perbandingan 1:2 yaitu $125 \mu \mathrm{L}$ ekstrak dan $250 \mu \mathrm{L}$ etanol $50 \%$. Ditambahkan sebanyak $500 \mu \mathrm{L} \mathrm{AlCl}_{3}$ ke dalam ekstrak dan dikocok hingga homogen, kemudian didiamkan selama 30 menit. Pengukuran absorbansi dilakukan dengan panjang gelombang $415 \mathrm{~nm}$.

\section{Penentuan kandungan total fenol}

Penetapan kadar fenol total dilakukan dengan metode kolorimetri dengan asam galat (GAE) sebagai standar (Rita et al., 2016) Sebanyak 0,1 gram sampel (ekstrak n-butanol) dimasukkan dalam labu ukur $5 \mathrm{~mL}$ kemudian diencerkan dengan pelarut metanol. Sampel divortex dan disaring hingga diperoleh filtratnya. Sebanyak $100 \mu \mathrm{L}$ filtrat direaksikan dengan $100 \mu \mathrm{L}$ reagen Follin-Ciocalteu. Larutan tersebut divortex dan didiamkan selama 6 menit. Sebanyak $800 \mu \mathrm{L} \mathrm{Na}_{2} \mathrm{CO}_{3} 5 \%$ direaksikan dengan larutan tersebut, dihomogenkan dan didiamkan selama 30 menit. Pengukuran absorbansi dilakukan dengan panjang gelombang $760 \mathrm{~nm}$. 


\section{HASIL DAN PEMBAHASAN}

\section{Ekstraksi dan Uji Fitokimia Senyawa Flavonoid dan Fenol}

Maserasi $1 \mathrm{~kg}$ serbuk kulit pisang kepok kuning dengan $7000 \mathrm{~mL}$ etanol 96\% (2 x 3500 $\mathrm{mL}$ ) menghasilkan ekstrak kental sebanyak 80,92 g. Sebanyak $20 \mathrm{~g}$ ekstrak kental tersebut dilarutkan dengan etanol $70 \%$, selanjutnya etanol diuapkan sehingga tersiasa ekstrak air. Ekstrak air dipartisi menggunakan pelarut nheksana, etil asetat, dan n-butanol, dan dihasilkan 1,3758 g ekstrak kental n-heksana yang berwarna coklat kekuningan, 3,5818 g ekstrak kental etil asetat yang coklat kemerahan, dan 1,0762 g ekstrak kental nbutanol yang berwarna coklat kekuningan. Jumlah hasil partisi tersebut sangat rendah jika dibandingkan jumlah ekstrak kental yang dipartisi, hal ini dimungkinkan karena jumlah metabolit sekunder pada ekstrak tersebut lebih sedikit dibandingkan pada ekstrak air. Selanjutnya keempat ekstrak tersebut dilakukan uji fitokimia flavonoid dan fenol. Hasil uji flavonoid dan fenol keempat ekstrak disajikan pada Tabel 1.

Pada uji skrining flavonoid dengan pereaksi Willstater, Bate Smith, dan $\mathrm{NaOH}$ $10 \%$ menunjukkan perubahan warna yang menandakan positif flavonoid. Sedangkan pada uji fenol dengan pereaksi $\mathrm{FeCl}_{3}$ menghasilkan warna hijau kehitaman yang menandakan positif fenol. Mengacu pada tabel reaksi warna flavonoid (Geissman, 1962) ekstrak etanol dan etil asetat diduga mengandung senyawa flavononol, sedangkan ekstrak n-butanol dan n-heksana diduga mengandung senyawa flavonol. Selanjutnya keempat ekstrak tersebut dilakukan pengujian aktivitas antibakteri Staphylococcus aureus dan Escherichia coli.

\section{Uji Aktivitas Antibakteri}

Hasil uji aktivitas antibakteri ekstrak kental etanol, ekstrak n-heksana, ekstrak etil asetat, dan ekstrak n-butanol terhadap bakteri S.aureus dan E.coli dipaparkan pada Tabel 2. Tabel 2 menunjukkan bahwa ekstrak kental etanol tidak menunjukkan adanya zona hambat terhadap bakteri S.aureus dan E.coli. Hal ini kemungkinan dikarenakan gabungan senyawa dari ekstrak n-butanol, etil asetat, dan nheksana bersifat antagonis. Kusmayanti dan Agustini (2007) melaporkan bahwa ekstrak kasar $P$. cruentum tidak mampu menghambat pertumbuhan bakteri gram positif (B. subtilis dan $S$. aureus) maupun negatif (E.coli) dikarenakan pelarut etanol dapat melarutkan hampir sebagian besar komponen senyawa yang terdapat dalam biomassa mikro alga $P$. cruentum.

Tabel 1. Hasil Penapisan Fitokimia

\begin{tabular}{|c|c|c|c|c|}
\hline No. & Ekstrak & Pereaksi & Perubahan warna & Keterangan \\
\hline \multirow[t]{4}{*}{1.} & Etanol & $\mathrm{Mg}-\mathrm{HCl}$ & Kuning kecoklatan menjadi kuning & +Flavonoid \\
\hline & & $\mathrm{HCl}$ & Kuning kecoklatan menjadi merah tua & +Flavonoid \\
\hline & & $\mathrm{NaOH} 10 \%$ & Kuning kecoklatan menjadi merah kecoklatan & +Flavonoid \\
\hline & & $\mathrm{FeCl}_{3}$ & Kuning kecoklatan menjadi hijau kehitaman & + Fenol \\
\hline \multirow[t]{4}{*}{2.} & n-butanol & $\mathrm{Mg}-\mathrm{HCl}$ & Kuning bening menjadi keruh dan berbuih & -Flavonoid \\
\hline & & $\mathrm{HCl}$ & Kuning bening menjadi merah bata & +Flavonoid \\
\hline & & $\mathrm{NaOH} 10 \%$ & Kuning bening menjadi kuning tua & +Flavonoid \\
\hline & & $\mathrm{FeCl}_{3}$ & Kuning bening menjadi hijau kehitaman & + Fenol \\
\hline \multirow[t]{4}{*}{3.} & Etil asetat & $\mathrm{Mg}-\mathrm{HCl}$ & Kuning menjadi orange dan berbuih & +Flavonoid \\
\hline & & $\mathrm{HCl}$ & Kuning menjadi merah tua & +Flavonoid \\
\hline & & $\mathrm{NaOH} 10 \%$ & Kuning menjadi coklat & +Flavonoid \\
\hline & & $\mathrm{FeCl}_{3}$ & Kuning menjadi hijau kehitaman & + Fenol \\
\hline \multirow[t]{4}{*}{4.} & n-heksana & $\mathrm{Mg}-\mathrm{HCl}$ & Kuning menjadi coklat & -Flavonoid \\
\hline & & $\mathrm{HCl}$ & Kuning menjadi merah & +Flavonoid \\
\hline & & $\mathrm{NaOH} 10 \%$ & Kuning menjadi orange & +Flavonoid \\
\hline & & $\mathrm{FeCl}_{3}$ & Kuning menjadi kuning pekat & + Fenol \\
\hline
\end{tabular}


Aktivitas Antibakteri Ekstrak Kulit Pisang Kepok Kuning (Musa paradisiaca L.) Terhadap Bakteri Staphylococcus aureus dan Escherichia coli Serta Penentuan Total Flavonoid dan Fenol Dalam Fraksi Aktif

Tabel 2. Hasil Uji Aktivitas Antibakteri Ekstrak Kental dan Hasil Partisi

\begin{tabular}{ccc}
\hline Sampel & $\begin{array}{c}\text { Diameter } \\
\text { Hambat } \\
\text { S.aureus }\end{array}$ & $\begin{array}{c}\text { Diameter } \\
\text { Hambat } \\
\text { E.coli }\end{array}$ \\
\hline $\begin{array}{c}\text { Kontrol negatif } \\
\text { (tween 10\%) }\end{array}$ & 0 & 0 \\
Etanol & 0 & \\
n-butanol 10\% & 14,75 & 14 \\
Etil asetat 10\% & 0 & 10,7 \\
n-heksana 10\% & 6,75 & 11,7 \\
Kontrol positif & 29,125 & 24,35 \\
(tetrasiklin) & & \\
\hline
\end{tabular}

Ekstrak n-butanol 10\% mampu menghambat kuat bakteri $S$. aureus dan E. coli, sedangkan ekstrak etil asetat $10 \%$ tidak mampu menghambat bakteri S.aureus tetapi mampu menghambat kuat bakteri E.coli. Ekstrak nheksana $10 \%$ memiliki aktivitas antibakteri yang tergolong sedang sampai kuat terhadap bakteri $S$. aureus dan E. coli. Kontrol negtif (tween 10\%) tidak menunjukkan aktivitas penghambatan terhadap kedua bakteri tersebut.

Berdasarkan zona hambat yang terbentuk, ekstrak n-butanol memiliki respon hambatan pertumbuhan yang lebih tinggi terhadap bakteri $S$. aureus. Perbedaan aktivitas penghambatan bakteri tersebut disebabkan oleh jumlah kandungan polifenol dan flavonoid pada ekstrak serta perbedaan tingkat sensitivitas bakteri yang dipengaruhi oleh struktur dinding sel bakteri.

Bakteri gram positif memiliki tingkat sensitivitas yang cenderung lebih tinggi dibandingkan bakteri gram negatif dikarenakan struktur dinding selnya lebih sederhana sehingga senyawa antibakteri mudah masuk sel bakteri gram positif (Sianrsih et al., 2016).

Besarnya aktivitas penghambatan bakteri gram positif disebabkan juga karena lapisan peptidoglikan yang bersifat polar lebih mudah ditembus oleh senyawa flavonoid kulit pisang yang bersifat polar juga. Sesuai hasil penelitian Ningsih et al., 2013, ekstrak kental bonggol pisang kepok kuning memiliki aktivitas penghambatan yang tinggi terhadap bakteri S.aureus dibandingkan E.coli dengan diameter hambat masing-masing sebesar 20,39 $\mathrm{mm}$ dan $18,96 \mathrm{~mm}$.

\section{Penentuan Konsentrasi Hambat Minimum (KHM)}

Penentuan Konsentrasi Hambat Minimum (KHM) dilakukan pada ekstrak n-butanol karena memiliki aktivitas yang paling tinggi terhadap bakteri Staphylococcus aureus dan Eschericia coli. Penentuan KHM dilakukan dengan metode yang sama seperti pengujian aktivitas antibakteri. Hasil penentuan KHM disajikan pada Tabel 3. Ekstrak n-butanol kulit pisang kepok kuning memiliki nilai KHM sebesar $0,5 \%$ untuk bakteri Staphylococcus aureus dan $0,1 \%$ untuk bakteri Eschericia coli.

Untuk mengetahui ada atau tidaknya perbedaan yang signifikan antar konsentrasi dari hasil yang diperoleh, maka dilakukan analisis statistika menggunakan Uji One Way ANOVA. Berdasarkan Tabel 3 dapat diketahui bahwa terdapat perbedaan yang signifikan antar konsentrasi dalam menghambat pertumbuhan S.aureus dan E.coli. Namun, pada konsentrasi $2,0 \%$ dan $1,0 \%$ tidak terdapat perbedaan nyata dalam menghambat pertumbuhan S.aureus.

Tabel 3. Hasil penentuan konsentrasi hambat minimum (KHM) untuk bakteri S.aureus dan E.coli

\begin{tabular}{ccc}
\hline Konsentrasi & $\begin{array}{c}\text { Diameter } \\
\text { Hambat } \\
\text { S.aureus }\end{array}$ & $\begin{array}{c}\text { Diameter } \\
\text { Hambat } \\
\text { E.coli }\end{array}$ \\
\hline 8,0 & $14,75 \mathrm{a}$ & $10,75 \mathrm{ab}$ \\
6,0 & $13,75 \mathrm{~b}$ & $10,5 \mathrm{~b}$ \\
4,0 & $8,5 \mathrm{c}$ & $9,5 \mathrm{c}$ \\
2,0 & $8 \mathrm{~d}$ & $11 \mathrm{a}$ \\
1,0 & $7,75 \mathrm{~d}$ & $8,25 \mathrm{~d}$ \\
0,5 & $6,75 \mathrm{e}$ & $6,25 \mathrm{e}$ \\
0,1 & $0 \mathrm{f}$ & $7 \mathrm{f}$ \\
\hline
\end{tabular}

*Angka yang diikuti huruf yang sama menunjukkan tidak berbeda nyata berdasarkan Duncan Multiple Range Test pada taraf $5 \%$

Menurut Pelezar dan Chan (1986), besarnya konsentrasi berbanding lurus dengan besarnya aktivitas. Hasil ini didukung oleh penelitian dari Sinarsih et al., 2016 bahwa ekstrak etanol daun trembesi dengan konsentrasi tinggi menghasilkan diameter zona hambat pertumbuhan bakteri yang semakin besar. Tetapi terdapat penurunan diameter hambatan pada beberapa konsentrasi yang lebih besar yaitu pada bakteri Eschericia coli dengan konsentrasi ekstrak $0,5 \%$ dan $4 \%$. Hal tersebut dilaporkan pada penelitian Elifah (2010), dimana 
peningkatan konsentrasi antibakteri tidak selalu berpengaruh terhadap peningkatan diameter daerah hambat, mungkin dikarenakan kecepatan senyawa antibakteri yang berbeda-beda untuk berdifusi pada media agar serta perbedaan konsentrasi dan jenis senyawa antibakteri yang memberikan efek penghambatan yang berbeda pada lama waktu tertentu.

\section{Penentuan Kandungan Total Flavonoid dan Fenol}

Penentuan kandungan total flavonoid dan fenol dilakukan terhadap ekstrak n-butanol yang positif mengandung flavonoid dan fenol pada uji skrining, dan memiliki aktivitas antibakteri tertinggi. Dalam penentuan kadar total flavonoid digunakan kuersetin (QE) sebagai larutan standar. Kuersetin termasuk senyawa flavonoid kuat golongan flavonol yang mempunyai gugus keto pada atom C-4 serta gugus hidroksi pada atom $\mathrm{C}-3$ atau $\mathrm{C}-5$ yang bertetangga. Flavonol diketahui sebagai senyawa penciri adanya flavonoid karena keberadaanya yang banyak tersebar dalam tumbuhan (Azizah et al., 2014). Sedangkan untuk penentuan kadar senyawa fenol total, larutan standar yang digunakan adalah asam galat (GAE).

Tabel 4. Kandungan Total Flavonoid dan Fenol Ekstrak n-butanol Kulit Pisang Kepok

\begin{tabular}{ccccc}
\hline \multirow{2}{*}{ Ekstrak } & \multicolumn{2}{c}{$\begin{array}{c}\text { Total Senyawa } \\
\text { Flavonoid (QE) }\end{array}$} & \multicolumn{2}{c}{$\begin{array}{c}\text { Total Senyawa } \\
\text { Fenol (GAE) }\end{array}$} \\
\cline { 2 - 5 } & $\%$ & $(\mathrm{mg} / 100 \mathrm{~g})$ & $\%$ & $(\mathrm{mg} / 100 \mathrm{~g})$ \\
\hline $\begin{array}{c}\mathrm{n}- \\
\text { butanol }\end{array}$ & 0,06 & 60 & 0,15 & 150 \\
\hline
\end{tabular}

Asam galat merupakan senyawa fenolik turunan asam hidroksibenzoat yang stabil, relatif murah, dan termasuk asam fenol sederhana (alami) (Lee et al., 2003).

Kadar total flavonoid yang diperoleh dihitung berdasarkan persamaan regresi linier kurva standar kuersetin. Persamaan regresi untuk absorbansi kuersetin pada konsentrasi 0, 1, 2, 3, 4 , dan 5 ppm yaitu $\mathrm{y}=0,0385 \mathrm{x}-0,0046$ dengan nilai koefisien korelasi (r) sebesar 0,9965. Sedangkan kadar total fenol ang diperoleh dihitung berdasarkan persamaan regresi linier kurva standar asam galat. Persamaan regresi untuk absorbansi asam galat pada konsentrasi 0 ,
$2,4,8,12,16$, dan $20 \mathrm{ppm}$ yaitu $\mathrm{y}=0,0473 \mathrm{x}-$ 0,0014 dengan nilai $r$ sebesar 0,9990 .

Menurut Rita et al. (2016) aktivitas flavonoid dan fenol sebagai antibakteri dikarenakan pembentukan kompleks dengan protein bakteri melalui ikatan hidrogen, ikatan kovalen, dan ikatan hidrofobik, sehingga dapat menonaktifkan enzim dari bakteri. flavonoid juga dapat mengganggu membran bakteri yang menyebabkan terganggunya fungsi permeabilitas selektif dan fungsi transpor aktif. Komposisi protein dari sel-sel bakteri menjadi terganggu, yang akan berujung pada keluarnya makromolekul, dan ion dari sel. Jadi sel-sel bakteri menjadi hilang bentuknya, dan terjadi lisis.

\section{SIMPULAN DAN SARAN}

\section{Simpulan}

Berdasarkan hasil penelitian yang diperoleh, dapat disimpulkan bahwa:

Fraksi n-butanol kulit pisang kepok kuning (Musa paradisiaca L.) mampu menghambat kuat bakteri Staphylococcus aureus dan Escherichia coli dengan diameter hambat tertinggi yaitu $14,75 \mathrm{~mm}$ dan $14 \mathrm{~mm}$ serta memiliki nilai KHM sebesar $0,5 \%$ untuk bakteri Staphylococcus aureus dan $0,1 \%$ untuk bakteri Eschericia coli dengan diameter hambat masingmasing 6,75 $\mathrm{mm}$ dan $7 \mathrm{~mm}$.

Kandungan total flavonoid dalam fraksi nbutanol adalah $0,06 \%$, sedangkan kandungan total fenolnya adalah $0,15 \%$.

\section{Saran}

Perlu dilakukan penelitian lanjutan mengenai isolasi senyawa aktif antibakteri pada ekstrak kulit pisang kepok kuning (Musa paradisiaca L.), dan mengidentifikasi senyawa aktif tersebut untuk mengetahui golongan dan struktur dari senyawa aktif yang berpotensi sebagai antibakteri.

\section{UCAPAN TERIMA KASIH}

Ucapan terimakasih penulis sampaikan kepada LPPM atas bantuan dana yang diberikan, Ibu Sri Rahayu Santi, S.Si., M.Si, A.A.I.A. Mayun Laksmiwati, S.Si., M.Si, dan Bapak I Nengah Simpen, S.Si., M.Si atas masukan dan sarannya, serta semua pihak yang telah mendukung dalam penyelesaian penelitian ini. 


\section{DAFTAR PUSTAKA}

Atun, S., Arianingrum, R., Handayani, S., Rudyansah, dan Garson, M., 2007, Identifikasi Dan Uji Aktivitas Antioksidan Senyawa Kimia Dari Ekstrak Metanol Kulit Buah Pisang (Musa paradisiaca Linn.), Indo. J. Chem., 7 (1): 83 - 87.

Azizah, D. N., Kumolowati, E., dan Faramayuda, F., 2014, Penetapan Kadar Flavonoid Metode $\mathrm{AlCl}_{3}$ Pada Ekstrak Metanol Kulit Buah Kakao (Theobroma cacao L.), Jurnal Ilmiah Farmasi, 2 (2): 45-49.

Chang, C., Yang, M., Wen, H., and Chem, J., 2002, Estimation of Total Flavonoid Content in Propolis by Two Complementary Colorimetric Methods, Journal Food Drug Analysis, 10: 178-182.

Elifah, Esty, 2010, Uji Antibakteri Fraksi Aktif Ekstrak Metanol Daun Senggani (Melastoma candidum, D.Don) Terhadap Escherichia coli dan Bacillussubtilis Serta Profil Kromatografi Lapis Tipisnya, Skripsi, FMIPA UNS, Surakarta.

Fagbemi, J.F., Ugoji, E., Adenipekun, T, Adelowotan O., 2009, Evaluation of the antimicrobial properties of unripe banana (Musa sapientum L.), lemon grass (Cymbopogon citratus S.) and turmeric (Curcuma longa L.) on pathogens. Afr $J$ Biotechnol, 8(7): 1176- 1182.

Faradhila, 2015, Uji Aktivitas Antibakteri Ekstrak Etanol 96\% Limbah Kulit Pisang Kepok Kuning (Musa balbisiana) Terhadap Bakteri Penyebab Jerawat (Staphylococcus epidermidis, Staphylococcus aureus, dan Propionibacterium acne), Skripsi, Fakultas Ketokteran dan Ilmu Kesehatan, UIN Syarif Hidayatullah, Jakarta.

Geissman, T. A., 1962, The Chemistry of Flavonoid Compound, 3-5, The Mac Millan Company, New York.

Karsinah, Lucky H. M., Suharto, Mardiastuti, H. W., 1994, Buku Ajar Mikrobiologi, Binarupa Aksara, Bandung.

Kumar, K. P. Sampath, Bhowmik, Debjit, Duraivel, S., Umadevi, M., 2012, Traditional and Medicinal Uses of Banana, Journal of Pharmacognosy and Phytochemistry, 1(3): 62.
Kusmayati dan Agustini, N. W. R., 2007, Uji Aktivitas Senyawa Antibakteri dari Mikroalga (Porphyridium cruentum), Biodiversitas, 8(1): 48-53.

Lee, K.I., Kim, Y.J., and Lee, C.H., 2003, Cocoa Has Mora Phenolic Phytochemical and Higher Antioksidant Capacity than Teas and Red Wine, J.Agric. Food Chem., 51: 7292-7295.

Ningsih, A. P., Nurmiati, dan Agustien, A., 2013, Uji Aktivitas Antibakteri Ekstrak Kental Tanaman Pisang Kepok Kuning (Musa paradisiaca Linn.) terhadap Staphylococcus aureus dan Eschericia coli, Jurnal Biologi, Universitas Andalas, 2(3): 207-213.

Pelczar, M. J., dan Chan, E., C, S., 1988, DasarDasar Mikrobiologi, Jilid 1, a.b. Hadioetomo, R. S., UI Press, Jakarta.

Rita, W. S., Swantara, I. M. D., Asih, I. A. R. A., Sinarsih, N. K., dan Suteja, I. K. P., 2016, Total flavonoid and phenolic contents of n-butanol extract of Samanea saman leaf and the antibacterial activity towards Escherichia coli and Staphylococcus aureus, AIP Conference Proceedings, 1718: 060005-1-060005-6.

Sari, P. P., Rita, W. S., dan Puspawati, N. M., 2014, Identifikasi dan uji Aktivitas Senyawa Tanin dari Ekstrak Daun Trembesi (Samanea saman (Jacq.) Merr) Sebagai Antibakteri Escherichia coli (E.coli), Jurnal Kimia, 9(1): 27-34.

Sinarsih, N.K., Rita, W.S., Puspawati, N.M. 2016. Uji Efektivitas Ekstrak Daun Trembesi (Samanea saman (Jacq.) Merr) sebagai Antibakteri Escherichia coli dan Staphylococcus aureus, Cakra Kimia, 4(2):120-128.

Subrata, K. B., Anusua, C., Joysree, D., Sheikh, Z. R., Manik, C. S., Utpal, K. K., 2011, Investigation of antibacterial activities of ethanol extracts of Musa paradisiaca Lam. Journal of Applied Pharmaceutical Science, 01 (06): 133-135. 